\title{
Oil and Gas Reservoirs in the Lower Triassic Deposits in the Arctic Regions of the Timan-Pechora Province
}

\author{
N. Timonina ${ }^{(\bowtie)}$ \\ Institute of Geology Komi SC UB RAS, Syktyvkar, Russia \\ nntimonina@geo.komisc.ru
}

\begin{abstract}
The Lower Triassic sediments of the Timan-Pechora oil and gas bearing province were studied by the complex of lithological, petrophysical and geochemical methods. It is established that productive deposits are represented by various-grained sandstones that formed in arid climates in the vast alluviallacustrine plain. The research allowed to study and characterize the structure features of rock and mineral aggregates, forming a pore space. The high heterogeneity of the composition and structure of the cement minerals of the reservoir caused by local facies-paleogeographic sedimentation conditions, were the cause of the significant variability of the pore space. Rocks reservoirs are complex, with high content of clay component, an effective development of which requires special methods of stimulation.
\end{abstract}

Keywords: Oil and gas bearing province $\cdot$ Lithological types $\cdot$ Reservoir $\cdot$ Clay minerals $\cdot$ Pore space $\cdot$ Porosity $\cdot$ Permeability

\section{Introduction}

In recent years, researches were intensified in the field of the formation of natural reservoirs. The basis for sedimentological reconstructions lies in the idea that the morphology and filtration characteristics of natural reservoirs are largely predetermined by ancient sedimentation situations, which are closely associated with the tectonic history of the territories. The Timan-Pechora province occupies the region of the northeastern Russian platform. Hydrocarbon accumulation occurred in Triassic rocks largely in the northern part of the basin, where pools were found in the rocks in the Varandey, Toravey, Labagan fields of the Sorokin swell, Kumzhinskoe, Korovinskoe in Denisov Depression. Triassic deposits are distributed almost throughout the TimanPechora oil and gas bearing province, with the exception of the axial zones of large positive structures. The Lower Triassic includes strata of the Charkabozhsky suite, which thickness varies from the first meters in the southwest (in the Seduyahinsky swell) to $380 \mathrm{~m}$ in the central part of the Kolvinsky megaswell, the Khoreyver depression, the average thickness of the suite is 150-250 m (Morakhovskaya 2000). The sediments are represented by rhythmic alternation of red-brown clays, greenishgray siltstones and gray sandstones with conglomerates and gravelites. Sandstones are characterized by a variety of granulometric composition from fine to coarse-grained, as well as a wide range of textures: massive, diagonal and horizontal bedding. 


\section{Methods and Approaches}

Oil and gas reservoirs are geological bodies consisting of reservoir beds, lenses, and reservoirs of weakly and impermeable rocks of intra-reservoir tires, forming a single hydrodynamic system, bounded below and above by inter-reservoir tires. Accumulation of hydrocarbons in the reservoir and their safety are determined by the quality of each of the elements. The main reason for the differentiation of natural reservoirs by properties is their formation. The structural features of sedimentary layers determine the patterns of distribution of collectors and seals in them, their interrelationship, and ultimately predetermine the morphology and properties of natural reservoirs.

This paper proposes a conceptual model of the formation of a natural reservoir confined to the deposits of the Charkabozhskaya suite. The construction of working models was carried out using the results of complex processing of all available information, including well-logging, and study of core material.

The results of this work are based on combination of analytical tools, including polarizing microscope, scanning electron microscope, X-ray diffraction and electron microprobe, were used in order to identify and estimate authigenic mineral type sand to determine paragenetic sequences.

\section{Results and Discussion}

At the first stage of creating a geological model of a terrigeneous reservoir, separate strata were correlated. The selection and tracing of the layers was carried out by logging diagrams; local surfaces associated with homogeneous rocks, more or less sustained over the area, were taken as main reference points; within individual areas, additional benchmarks were used, which were characterized by stable geophysical characteristics. Two productive formations were confined to the Lower Triassic deposits. To maximally take into account the features of the structure of productive layers at the first stage of modeling, the study of microscopic in homogeneities of productive sediments was carried out on the basis of lithofacies and sedimentation models.

The main reason for the heterogeneity of natural reservoirs in terms of the properties of the reservoirs and tires that form them is the conditions of their formation. Detailed lithofacies analysis of Lower Triassic deposits was carried out, based on a set of investigations by both domestic (Muromtsev 1984; Bruzhes 2010; Morozov 2013) and foreign researchers (Celli 1989; Hellem 1983). The analysis of geological and geophysical information, the study of well cores, and the interpretation of well logging data allowed reconstructing conditions for the formation of lower Triassic natural reservoirs. The formation of these sediments took place in the continental conditions of the alluvial plain.

According to classification by A.G. Kossovskaya and M.I. Tuchkova (Kossovskaya, Tuchkova 1988) sandstones fall into the field of polymictic $\left(\mathrm{SiO}_{2}\right.$ content 62 $78 \%)$ and volcanictic $\left(\mathrm{SiO}_{2}\right.$ content $\left.54-64 \%\right)$. According to classification of Pettijohn (1976) points of the composition of sandstones are localized in the fields of graywacke. 
Dominant cement minerals in Triassic sandstones include calcite, kaolinite, smectite, illite, and chlorite. Carbonate cement include pure calcite and siderite. The clear transparency and delicate crystalline habit of most of the clay, as revealed by microscope and SEM analysis, leads us to conclusion that the most clays in these sandstones are authigenic. Kaolinite occurs mostly as pore-lining and pore-filling cement, some of them appear as visible alteration of detrital feldspars. The distribution of kaolinite is uneven both in the section and in area. In the transition from coarse to fine-grained sediments, a decrease in the content of kaolinite is noted. Chlorite is common as pore-filling and lining cement. Smectite occurs both as grain-coating and filling pores. The studied deposits are characterized by a wide distribution of smectite minerals with increasing content upward the section. In the fine-grained sandstones of the basal stratum, its content does not exceed 50-60\%, whereas in the upper part of the section its amount increases to $80-90 \%$. The distribution and amount of clay minerals in sandstone cement is determined by both conditions of sedimentation and postsedimentation transformations. The most widespread collectors are of III-V classes according to the A.A. Khanin classification (Khanin 1976). Class VI reservoirs are characteristic of floodplain formations and represented by aleurolites and fine-grained sandstones, in which large pore channels are practically absent. Class V collectors are represented by fine-grained sandstones with pore cement predominantly of smectite composition, low values of filtration properties are due to the insignificant content of large pore channels (less than 5\%) and increasing number of non-filtered pores. These formations were deposited in floodplain conditions. The class IV reservoirs include fine- and medium-grained sandstones with polymineral cement: clayey pore and carbonate clot-pore type.

Collectors of II-III classes are represented by coarse-grained and medium-grained poorly sorted sandstones with pore-type cement, formed in an environment with a relatively quiet hydrodynamic regime.

\section{Conclusions}

The analysis of the reservoir properties of sandstones shows that sandstones formed under channel conditions are characterized by high median and average values of porosity and permeability, respectively $24 \%$ and $20.8 \%$ (porosity), $56 \cdot 10^{-12}$ and $40 \cdot 10^{-12} \mathrm{~m}^{2}$, the lowest values characterize sediments formed in floodplain conditions: the median values of porosity and permeability do not exceed $11 \%$ and $0.6 \cdot 10^{-12} \mathrm{~m}^{2}$, arithmetic averages reach $14 \%$ and $1.6 \cdot 10^{-12} \mathrm{~m}^{2}$. Analysis of the graphs of the dependence of porosity-permeability for productive layers showed that the highest values of filtration properties were typical to deposits of the basal layer, where I-II class reservoirs were identified.

A reliable seal of subregional distribution is the deposits of the Upper charkabojskaya sub-suite, having high quality and thickness. Minerals of the smectite dominate in the mineral composition, chlorite and illite are also present. Middle-Upper Triassic clays are floodplain and lake originated, in their composition chlorite and illite predominate, which reduces the quality of the foamed seal compared to the Charkabozhskaya seal. 
The differences in the composition and type of cement requires an individual approach, a balanced choice of technologies in determining the development strategy of fields and careful selection of a set of methods aimed at increasing oil recovery for different sections of fields.

Acknowledgements. The article was created under partial financial support by project of Ural Branch of Russian Academy of Sciences № 18-5-5-13 "The Geological Models, Environmental Conditions and Prospects of Oil and Gas bearing of Phanerozoic deposits in Arctic regions of Timan-Pechora province".

\section{References}

Bruzhes LN, Izotov VG, Sitdikova LM (2010) Litofacial conditions of formation of the horizon of the Yu1 Tevlinsko-Russkinskoye field of the West Siberian oil and gas province. Georesources 2(34):6-9

Celli RCh (1989) Ancient sedimentation. Nedra, Moscow, p 294

Hellem E (1983) Interpretation of facies and stratigraphic sequence. Mir, Moscow, p 328

Khanin AA (1976) Petrophysics of oil and gas reservoirs. Nedra, Moscow, p 259

Morakhovskaya ED (2000) Trias of the timan-ural region (reference sections, stratigraphy, correlation). Biochronology and correlation of the Phanerozoic oil and gas basins of Russia, vol 1, p 80. SPb: VNIGRI

Morozov VP, Shmyrina VA (2013) Influence of secondary changes in reservoir rocks on reservoir properties of the БС111 and ЮC11 productive layers of the Kustovoye deposit. Uchenye zapiski Kazan University, Kazan, vol 155, pp 95-98

Muromtsev VS (1984) Electrometric geology of sand bodies - lithological traps of oil and gas. Nedra, p 260

Pettijohn FJ, Potter PE, Siever R (1976) Sand and sandstone. Mir, Moscow, p 536

Open Access This chapter is licensed under the terms of the Creative Commons Attribution 4.0 International License (http://creativecommons.org/licenses/by/4.0/), which permits use, sharing, adaptation, distribution and reproduction in any medium or format, as long as you give appropriate credit to the original author(s) and the source, provide a link to the Creative Commons license and indicate if changes were made.

The images or other third party material in this chapter are included in the chapter's Creative Commons license, unless indicated otherwise in a credit line to the material. If material is not included in the chapter's Creative Commons license and your intended use is not permitted by statutory regulation or exceeds the permitted use, you will need to obtain permission directly from the copyright holder.

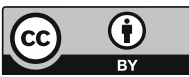

